\title{
Features of the Vital Activity of Xantogaleruca luteola Müll., 1766 (Coleoptera: Chrysomelidae) in the Protective Plantating of the Volgograd Region, Russia ${ }^{+}$
}

\author{
Olga Filimonova ${ }^{{ }^{*}}$, Maria Belitskaya ${ }^{1}$, Irina Gribust ${ }^{1}$ and Natal'ya Bakradze ${ }^{2}$
}

Citation: Filimonova, O.; Belitskaya, M.; Gribust, I.; Bakradze, N. Features of the Vital Activity of Xantogaleruca luteola Müll., 1766 (Coleoptera: Chrysomelidae) in the Protective Plantating of the Volgograd Region, Russia, in Proceedings of the 1st International Electronic Conference on Entomology, 1-15 July 2021, MDPI: Basel, Switzerland, doi:10.3390/IECE-10491

\section{Published: 1 July 2021}

Publisher's Note: MDPI stays neutral with regard to jurisdictional claims in published maps and institutional affiliations.

Copyright: (c) 2021 by the authors. Submitted for possible open access publication under the terms and conditions of the Creative Commons Attribution (CC BY) license (http://creativecommons.org/licenses /by/4.0/).
1 Federal Scientific Centre of Agroecology, Complex Meliorations and Protective Afforestation of the Russian Academy of Sciences (FSC of Agroecology RAS), 97, Universitetskiy Ave., Volgograd, Russia, 400062,

2 Volgograd State Social and Pedagogical University (VSSPU), 27 Lenin Ave., Volgograd, Russia, 400131,

* Correspondence: olga_filimonova_88@rambler.ru

+ Presented at the 1st International Electronic Conference on Entomology (IECE 2021), 1-15 July 2021; Available online: https://iece.sciforum.net/.

\begin{abstract}
In the Volgograd region, about $80.0 \%$ of the total dendrological composition is accounted for by representatives of the genus Ulmus. Phyllophages of different ecological groups are trophically associated with tree species Ulmus: leaf-eating - Operophtera brumata (Linnaeus, 1758), Lymantria dispar (Linnaeus, 1758), elm springtail Dicranura ulmi (Denis, 1775), Acleris boscana (Fabricius, 1794) and others; gall-forming - Tetraneura (Tetraneura) ulmi (Linnaeus, 1758), Eriosoma lanuginosum (Hartig, 1839) and E. ulmi (Linnaeus, 1758), etc.; leaf-mining insects - Stigmella viscerella (Stainton, 1853), St. lemniscella (Zeller, 1839), St. ulmivora (Fologne, 1860), Fenusa ulmi (Sundevall, 1847). Among them, leaf-eating pests are distinguished, which reduce decorativeness and worsen the condition of woody plants. One of the economically dangerous species is Xanthogaleruca luteola Müller, 1766 (Coleoptera: Chrysomelidae). For the first time, mass reproduction of the pest under the conditions of the region was observed in the middle of the 20th century. Currently, outbreaks of the number of X. luteola are noted periodically. The leaf beetle inhabits trees in plantations of all types and ecological categories, while the number of the pest varies depending on the ecological conditions of biotopes. This pest colonizes and assimilates foliage in the middle and lower parts of elm crowns (up to $81.7 \%$ of the total number). The maximum harm to the assimilation apparatus of trees is caused by the larvae of the leaf beetle.
\end{abstract}

Keywords: Ulmus L., protective planting; monitoring; pests; population of Xanthogaleruca luteola

The Volgograd region, located in the extreme southeast of the European part of the Russian Federation, is characterized by an arid climate with a sharply pronounced continental character [1]. Geographical confinement to the zone of dry steppes and semi-deserts determines its belonging to low-forest regions: with a total area of 13 thousand $\mathrm{km}$., forests in the region occupy only $4.3 \%$. Under these conditions, the best approach in solving many environmental problems becomes protective forestry [2, 3, 4]. Many decades ago, the Volgograd region became one of the significant landfills of protective forestry [3]. Today, old-age plantations possess here, in which $80.0 \%$ of the total dendrological composition is accounted for by representatives of the Ulmus generic complex [3, 4, 5]. Ecological plasticity, drought resistance, unsuitability to soil conditions have served to successfully naturalize and distribute Ulmus species in arid regions [5, 6, 7].

The progressive deterioration of the ecological situation leads to an increase in forest pathological threats to plantating, especially in regions of extreme climate. Against the background of a decrease in the resistance of woody plants, the transformation of biocenoses and the formation of specific communities of pests in them occurs $[2 ; 3 ; 5 ; 10]$. 
The aim of the study is to analyze the distribution of Xanthogaleruca luteola Müller, 1766 in protective afforestation of different types and ecological categories in Volgograd Region.

Studies were carried out in dendrological collections and protective forest plantations of the Federal Research Center for Agroecology of the Russian Academy of Sciences (FSUE «Volgogradskoye» cadastre. № 34:34:000000:122; Land use "Kachalinskoye" cadastre. No. 34:08:000000:6), as well as in recreational landscaping plantations of the city of Volgograd.

Assessment of forest-pathological state of woodlands differing in condition and level of anthropogenic impact was carried out using methods corresponding to the current guidelines on forest-pathological survey and monitoring of plantations [8].

The objects of research were insects living in Ulmus crowns. The species composition and number of phyllophages were evaluated using entomological mowing; visual accounting of insects on branches (pcs ./100 leaves) during the whole growing period [8]. The mass included species that damage more than $50 \%$ of the leaves in the crown of woody plants. Degree of defoliation of trees was determined visually according to basic methodological criteria [8].

\section{Research results and discussion.}

Woody plants of the genus Ulmus are distinguished by a high degree of adaptation and resistance to adverse factors. However, the creation of elm monocultures in the study area has now led to the degradation of plantings - the state of tree species in them is characterized by the III class of resistance.

In the spectrum of surveyed landscape elements, biotopes such as parks (max $B_{\text {mean }}$ ) and intra-quarter landings (min $\mathrm{B}_{\text {mean }}$ ) are distinguished by the level of life condition of ulm (Table 1). The stably weakened condition of elms is characteristic of squares and roadside plantings ( $B_{\text {mean }}=3.28-3.36$, respectively), due to the direct impact of vehicle exhaust gases and significant overpopulation of the soil cover.

Favorable conditions for maintaining the living optimum of woody plants Ulmus are formed in parks, forest bands and arboretum, where healthy or weakened trees prevail $\left(B_{\text {mean }}=1.82-1.69-1.87\right.$, respectively $)$.

Table 1. Condition of Ulmus woody plants in protective plantatings.

\begin{tabular}{cccccccc}
\hline \multirow{2}{*}{ Plantatings } & \multicolumn{4}{c}{ Status Category, $\%$} & \multicolumn{1}{c}{ Average score, Bmean } \\
\cline { 2 - 8 } & I & II & III & IV & V & VI & - \\
\hline Parks & 0,53 & 42,31 & 48,52 & 8,21 & 0,43 & 1,82 \\
\hline Squares & - & 43,22 & 36,43 & 14,41 & 4,24 & 1,70 & 3,26 \\
\hline Urban street & 2,87 & 2,87 & 48,01 & 34,07 & 11,06 & 1,12 & 3,51 \\
\hline Intra-quarter & 0,41 & 8,94 & 35,34 & 39,92 & 14,35 & 1,04 & 3,62 \\
\hline Protective forest bands & - & 27,1 & 42,9 & 20,3 & 8,9 & 0,9 & 1,69 \\
\hline Arboretum & 5,12 & 27,0 & 38,67 & 19,01 & 4,85 & 5,35 & 1,87 \\
\hline
\end{tabular}

Among the factors aggravating the situation, dendrophilic insects are of great importance $[1 ; 3 ; 10]$.

The core of the phyllophagous community of woody plants of the genus Ulmus consists of 145 species. The basis of the community is open-living insects $(80.69 \%$ of the total diversity of phyllophages).

Pests of foliage, which reduce ornamentation and worsen the condition of woody plants, play a significant role in changing the condition of protective forest bands and landscaping. In the Lower Volga region, phyllophages of different ecological groups are trophically associated with Ulmus tree species: leafy-eating - Operophtera brumata (Linnaeus, 1758), Lymantria dispar (Linnaeus, 1758), Dicranura ulmi (Denis \& Schiffi Acleris boscana (Fabricius, 1794), etc.; gall-forming - Tetraneura (Tetraneura) ulmi (Linnaeus, 1758), Eriosoma lanuginosum (Hartig, 1839) and E. ulmi (Linnaeus, 1758), etc.; leaf-mining 
insects - Stigmella viscerella (Steanton, 1853), St. lemniscella (Zeller, 1839), St. ulmivora (Fologne, 1860), Fenusa ulmi (Sundevall, 1847).

Among leaf-eating insects living in ulm crowns, Xanthogaleruca luteola Müll., Cladius ulmi (Linnaeus, 1758) and Dicranura ulmi D.S. are of great economic importance. It was found that Cladius ulmi successfully inhabits the most illuminated upper part of the ulm crown (14.6 pcs/unit. accounting). It should be noted that in the conditions of urbanization, the number of Cladius ulmi on ulms in plantations increases (by 35.0-42.1\%).

In field and roadside plantings along the right bank of the Volga along the Volga Upland, Dicraneura ulmi stands out in terms of numerical abundance in co-societies (an average of 11.6 and 10.2 pcs/units. accounting, respectively). In recreational landscaping, the quantitative abundance of this pest is $50.0 \%$ lower.

By the degree of destructive influence on tree species, the most aggressive defoliant is Xanthogaleruca luteola, whose destructive activity in the plantations of the Volgograd region is pronounced and stable over the past three decades[3; 9].

During the year, in the conditions of the Volgograd region, two generations of the pest develop. One tree accounts for up to 2.0-3.0 thousand individuals of the harmful phase, where the phyllophage destroys up to $70-80 \%$ of the leaf area, which determines the long-term leafless state of trees.

The distribution of the leaf beetle by density and the state of damage to the foliage of elms in plantations of different types is uneven. The density of X. luteola is highest in recreational and green plantations. The proportion of damaged leaves here reaches $91 \%$. The greatest extent of damage to the foliage of trees is noted in squares and street plantings $(0.91 \%)$. In the forest park, the damage is almost halved. In protective forest plantating, the number of this species is rather low $(0.05 \%)$.

Table 2. Distribution of Xantogaleruca luteola abundance in plantatings.

\begin{tabular}{ccccc}
\hline $\begin{array}{c}\text { Ecological categories of } \\
\text { plantings }\end{array}$ & Age & $\begin{array}{c}\text { Index } \\
\text { pollution, } \\
\text { IPA5 }\end{array}$ & $\begin{array}{c}\text { Recreational } \\
\text { Load }\end{array}$ & $\begin{array}{c}\text { Quantity of } \\
\text { beetles, } \\
\text { pcs ./100 leaves }\end{array}$ \\
\hline Field protective plantings & $50-65$ & 4,0 & weak & $7,2 \pm 0,3$ \\
\hline Roadside plantings & 40 & 11,0 & very high & $19,8 \pm 0,5$ \\
\hline Forest park & 50 & 9,1 & high & $18,5 \pm 0,6$ \\
\hline Parks & $10-70$ & 8,9 & high & $28,7 \pm 0,4$ \\
\hline Squares & $30-50$ & 10,7 & very high & $43,6 \pm 0,7$ \\
\hline Intra-quarter landings & $35-50$ & 5,8 & high & $36,8 \pm 0,6$ \\
\hline
\end{tabular}

It is interesting to note that the abundance of the pest is maximum in forest gardens subject to an intensive anthropogenic press. In field plantations, the quantitative abundance of beetles and leaf larvae on the leaves is minimal. This is primarily due to the significant reduction of negative anthropogenic effects and floristic variety affecting the diversity and abundance of these pests. Filling ecological niches with biotic agents contributes to an increase in community heterogeneity, a complication of interstitial relationships in entomocomplexes, resulting in a decrease in the numerical abundance of Xanthogaleruca luteola.

\section{Conclusion.}

The extreme climatic conditions of the Lower Volga region, combined with negative anthropogenic influence, determine the condition and viability of woody species of the Ulmus generic complex in plantatings, defined as "weakened" and "severely weakened."

Among stress factors negatively affecting Ulmus resistance and viability, phyllophages play an important role. Of these, Xanthogaleruca luteola poses an economic hazard. The number of pests is maximum in plantatings with high anthropogenic load indicators (roadside, intra-quarter plantings, squares), the average values of which vary from 19.8 to 43.6 pieces of individuals/100 leaves. Reducing the level of stress factors ensures a 
reduction in the number of pests in tree crowns: in field-protective plantations, this indicator on average ranges at the level of 7.2 pieces of individuals/100 leaves.

\section{References}

1. Belitskaya M.N. Dendrophages Ulmus spp. in the plantations of the Volga region // Science. Thought: electronic periodical journal. 2019. T. 9. No. 1. Pp. 24 - 39. [DOI: 10.25726 / NM.2019.77.24.002]

2. Belitskaya M.N., Gribust I.R. Dendrophages of forest reclamation complexes with the participation of tree introduced species in an arid zone // Socio-ecological technologies. 2019. No. 3. Pp. 343 - 361. [DOI: 10.31862 / 2500-2961-2019-9-3-343-361]

3. Belitskaya M.N., Filimonova O.S. Trophic structure of phyllophages in the plantations of Ulmaceae of an urbanized territory // Biological diversity - the basis of sustainable development. Materials of the international scientific and practical conference. Scientific editor: Okazova Zarina Petrovna. 2018. Pp. 56 - 60.

4. Dunaev E.A. Methods of environmental-entomological research//M.: MosgorSUN, 1997. - 44 p.

5. Yelnikova Yu.S., Yemelyanova N.Yu. On the issue of the biodiversity of insects - pests of green spaces in Volgograd // News of the St. Petersburg Forestry Academy. 2009. No. 187. Pp. 107 - 115.

6. Mozolevskaya E.G. Assessment of the state and stability of plantations//Forest protection technology .//M.: Ecology, 1991. Pp. $234-237$.

7. Mozolevskaya E.G., Kulikova E.G. Ecological categories of city-plantations//Ecology, monitoring and rational nature management: scientific. tr. M.: MGUL, 2000. Out. 302(1). Pp. 5 - 12.

8. Manual on Organization and Management of Forest Pathological Money-Toring in the Forests of Russia/Comp. A.D. Maslov, E.G. Mozolevskaya, H.A. Lisov and others - M.: VNIILM, 2001. - 86 p.

9. Seryi G.A. Mass breeding of the elm leaf beetle in the Volgograd region // Bulletin of the St. Petersburg Forestry Academy. 2009. No. 187. Pp. 304 - 310.

10. Belitskaya M.N., Gribust I.R., Nefed'eva E.E., Filimonova O.S., Golovanova M.A. The phyllophagous of woody plants of genus Ulmus in protective plantings of arid zone // IOP Conference Series: Earth and Environmental Science. Current Problems and Solutions. 2018. C. 012015. [DOI: 10.1088/1755-1315/115/1/012015] 